\title{
Explaining differentiation in European Union treaties
}

Thomas Winzen and Frank Schimmelfennig

Center for Comparative and International Studies, ETH Zurich, Switzerland

\begin{abstract}
Since the early 1990s, European integration has become increasingly differentiated. Analysing the conditions under which member states make use of the opportunity to opt out of, or exclude other countries from, European integration, we argue that different explanations apply to treaty and accession negotiations respectively. Threatening to block deeper integration, member states with strong national identities secure differentiations in treaty reform. In enlargement, in turn, old member states fear economic disadvantages and low administrative capacity and therefore impose differentiation on poor newcomers. Opt-outs from treaty revisions are limited to the area of core state powers, whereas they also occur in the market in the context of enlargement.
\end{abstract}

\section{Keywords}

European Union, Differentiated integration, Treaty reform, Enlargement

\section{Corresponding author}

Thomas Winzen, Center for Comparative and International Studies, ETH Zurich, Haldeneggsteig 4, 8092 Zurich, Switzerland. Email: thomas.winzen@eup.gess.ethz.ch. 


\section{Introduction}

Since the early 1990s, European integration has become differentiated integration. This period has been characterized by a far-reaching extension of the European Union's (EU) policy scope beyond the internal market, a progressive deepening of its competences, above all in monetary policy and justice and home affairs, and by more than a doubling of its membership (from 12 to 28). The EU has continuously been involved in negotiations on revisions to its treaty framework and the accession of candidates for membership. A uniform level of integration across all member states can still be considered the standard and proclaimed goal of these negotiations. As a matter of fact, however, the degree of integration is negotiable. Consequently, differentiated integration has become a permanent and increasingly important feature of the political order of the EU.

To give a few prominent examples, the British and Danish opt-outs from the single currency have been in place since the Treaty of Maastricht (1992). New member states, which joined the EU after the introduction of the euro in 1999, are generally excluded from monetary union upon accession. Although they are legally obliged to adopt the euro, it is in fact a matter of political choice whether or not they work towards meeting the conditions of convergence and apply for joining the common currency. Only seven of the 13 new member states, which have joined the EU since 2004, have adopted the single currency. The UK and Ireland have stayed out of the Schengen free-travel area since it was implemented in 1995, while Bulgaria and Romania have been blocked from joining since 2007. In addition, the UK and Ireland enjoy a flexible opt-out from the justice and home affairs policies subsumed under the Area of Freedom, Security and Justice (AFSJ), which allows them to opt in and out of legislation case by case.

At the same time, differentiated integration is a highly uneven development. Some countries among them most of the original six member states - have no treaty-based opt-outs at all; others most notably Denmark and the UK - have many. Some member states are differentially integrated 
based on their accession treaties; others as a result of revisions to the main European treaties. Likewise, differentiation is strong in some policy areas but absent from others.

This article analyses the choice for differentiated integration in the EU. We start from the assumption that treaty negotiations present the participating states with opportunities to opt out or exclude other countries from (further) integration in a variety of policy areas and ask which factors make it more likely that states actually use this opportunity. Based on descriptive analyses and findings reported in an earlier paper (Schimmelfennig and Winzen, 2014), we further assume that differentiated integration stemming from revisions of the EU's main treaties follows a different logic from differentiated integration originating in accession treaties. Treaty revisions, in which member states agree on the deepening of European integration - either by integrating new policies or by making already integrated policies more supranational - typically produce concerns by some member states that European integration is moving too far. This is true in particular for member states with a strong national identity, i.e. a large share of citizens claiming to identify with their country exclusively, and in salient core state powers such as monetary policy or border protection. By contrast, negotiations on EU enlargement typically produce concerns among the old member states that some of the new entrants may not be fully ready to participate in integrated policies, require too much assistance, or become strong competitors on the internal market or for EU budgetary resources. This applies in particular to poorer new member states with comparatively weak administrative capacity, both in the market as well as in core state powers.

In this article, we provide a comparative and longitudinal analysis of these propositions. Over a time period of 20 years, we examine the country- and policy-specific differentiation opportunities provided by EU treaty negotiations from Maastricht to the accession treaty with Croatia. Descriptively and in logistic regression analyses, we study the factors that have driven new differentiations in the Treaty on European Union and its revisions, the accession treaties, and policyspecific treaties such as Schengen and the European Stability Mechanism (ESM) Treaty. In line with our theoretical expectations, we find notable evidence that strong national identities explain new 
differentiation in deepening, and some, albeit less consistent support for the view that wealth (GDP per capita) accounts for new differentiations in enlargement. Moreover, it is clear that poor countries are not the ones producing differentiated integration in treaty revisions nor do nationally-oriented member states generate differentiations in the accession context. Finally, whereas differentiation in treaty revisions exists only in core state powers, it occurs in this area as well as in the market in enlargement.

Let it be stressed that, in making this argument, we do not dispute in any way that differentiation might also depend on preference constellations that are not rooted in structural conditions or plausible alternatives such as party ideology. Furthermore, we cannot credibly capture all intergovernmental bargaining dynamics such as the use of side-payments and issue-linkage. Taking these considerations into account satisfactorily would require a more case-oriented study whereas we offer a comparative and longitudinal perspective on structural factors that systematically encourage differentiation. Thus, we do not claim to provide an exhaustive account of differentiated integration but rather argue that systematic differences between countries contribute notably to an explanation - we discuss in what way, and highlight in the conclusion that this insight is important for understanding the Union's political development.

\section{Theory}

Differentiated integration is generally conceived as an institutional response to the increasing diversity and divisiveness of the EU (Dyson and Sepos, 2010: 5-6; Majone, 2009: 221; Stubb, 1997; Warleigh, 2002). As the EU expands to additional countries, it is likely to have an increasingly diverse membership with heterogeneous preferences and capabilities. As it expands its policy scope, it is increasingly likely to include value-laden, coercive or redistributive policies that provoke more intense conflict. Finally, as European integration deepens further, it triggers concerns about losses of national sovereignty and identity. Because both treaty revisions and accession treaties require 
unanimous intergovernmental agreement - and, in general, ratification by all member states, too heterogeneity and conflict threaten the EU with deadlocked negotiations. Differentiated integration offers a way out of deadlock by allowing the member states to cooperate at different levels of integration that fit their preferences and capabilities.

Theoretical accounts of differentiated integration have been more concerned with its consequences than with its causes. Based on collective action theory, Kölliker $(2001,2006)$ explores the conditions under which differentiated integration produces centrifugal or centripetal effects; Jensen and Slapin (2012) theorize how initial differentiation may lead to 'opt-out cascades'. By contrast, Hvidsten and Hovi (2015) show 'how differentiation and discontent in the short term may coexist with unity in the long term' (2015: 5); Adler-Nissen (2008, 2009, 2011) describes how informal norms and institutional practice mitigate the formal institutional divides created by differentiated integration. ${ }^{1}$

In this article, we seek to go beyond existing accounts in several ways. First, in contrast to studies focusing on the longer-term implications, we are interested in the country-level and policy-level factors that drive the initial choice for differentiated integration. Second, rather than focusing on a limited number of prominent cases or on specific contexts of differentiation such as enlargement or conflicts about the direction of integration, we seek to account for treaty-based differentiation in general. We take into account, however, that revisions or extensions of the main treaties and new accession treaties typically constitute diverse negotiation contexts with different drivers and actors and different issue and power constellations. Third, while we start from the general account of differentiated integration as an institutional solution overcoming deadlock in a situation of heterogeneity, we ask what kind of heterogeneity matters. For instances, heterogeneity can refer to both preferences and capacities, and it could be based on either ideological or material preferences (Holzinger and Schimmelfennig, 2012: 299). Finally, we concentrate on the fundamental, structural factors that drive the heterogeneity of state preferences and capacities and that shape governmental choices for differentiated integration systematically. Specifically, we argue that national identity drives the predominantly ideological heterogeneity, which triggers differentiated integration in the 
context of treaty revisions, whereas differences in wealth drive the predominantly material heterogeneity of preferences and capacities, which give rise to differentiated integration in the context of accession treaties.

Revisions of the main treaties are about the deepening of European integration. Typically, they expand the policy scope of the EU by removing additional policies from the exclusive competence of the member states, or they increase the level of centralization of already integrated policies by strengthening the pooling and delegation of policymaking, e.g. by moving from unanimous to majority voting, increasing the powers of the European Parliament, or delegating competences to the Commission and other supranational agencies. ${ }^{2}$ Mostly, member state governments negotiate and decide on deepening on the basis of efficiency-oriented preferences. Majority voting facilitates decision-making, and delegation improves policy coordination and the credibility of member state commitments (Moravcsik, 1998). In addition, however, some member states and societies have principled objections to transferring powers to the EU for fear of hollowing out national sovereignty. Such principled objections make it harder to reach intergovernmental agreement; they are also prone to triggering popular opposition to integration, which ties the hands of government in the negotiation process or causes domestic ratification to fail. The failed referendums on Denmark's or Sweden's adoption of the euro are cases in point.

The likelihood that such principled sovereignty concerns arise varies across policies and member states. As Stanley Hoffmann (1966) pointed out, integration in areas of 'high politics' should yield higher autonomy costs compared to 'low politics' integration. Taking Hoffmann's distinction as a point of departure, Genschel and Jachtenfuchs (2014: 10) define 'core state powers' (such as a state's army, police and justice system, currency, or public administration) as those functions and policies that have particularly strong 'institutional significance for state building' and are thus closely linked to sovereignty. Sovereignty concerns are prone to arise not in all member states but in those that tend towards strong national identities. Earlier research has shown that exclusive national identities reduce support for European integration (Carey, 2002; Hooghe and Marks, 2005). Hooghe 
and Marks further argue that exclusive national identities are likely to be activated if the scope and depth of integration increase perceptibly (Hooghe and Marks, 2008: 13). Moreover, 'Eurosceptic parties on the right rally opposition by stressing the defence of national sovereignty and identity considerations' (de Vries and Edwards, 2009: 6). As a result, the domestic ratification of treaty revisions is at risk. Governments of member states with strong national identities either seek optouts from deepening during the negotiations or are granted such opt-outs after a failed referendum. Where referendums are not possible, governments still risk losing electoral popularity if they ignore nationalist sentiment in the population. Where exclusive identities are prevalent, Euroscepticism is stronger, and voter-party congruence regarding European integration has the potential to affect election outcomes (de Vries, 2007). We suggest that, regarding the question at hand, public identity conceptions, rather than Euroscepticism more generally, are key because the parties that have sought to mobilise voters on the basis of opposition against new EU treaties have, so far, come mainly from the political right and appealed to voters' national identity (Kriesi et al., 2006; Hooghe and Marks, 2008). According to these considerations, a strong national identity increases a country's opposition to, and demand for differentiation from, treaty revisions - albeit only in the area of core state powers in which principled opposition to integration is relevant.

The opponents of further deepening are in a particularly strong bargaining position during negotiations on treaty revisions. They are the status quo powers that can block treaty revisions requiring unanimous agreement. This leaves member states desiring to move beyond what the opponents deem acceptable with two options. They can either offer them an opt-out from the deepening provisions of the treaty revision; or they can conclude an intergovernmental treaty outside the European treaty framework. We see examples for both options in the history of EU treaty-making. The British and Danish opt-outs from monetary union in the Treaty of Maastricht are the most prominent examples of the first option; the 1985 Schengen Agreement, which was only incorporated into the main treaties at Amsterdam in 1997, was the prototypical case of differentiated integration via separate treaty-making. Both cases lead to differentiated integration, in 
which a group of member states is exempted from areas of further deepening. These considerations lead to our first expectation:

H1: In treaty revisions, differentiated integration is more likely to apply to countries with a strong national identity, albeit only in the area of core state powers.

The second category of treaty-based change in European integration is enlargement. Accession treaties are about the widening of European integration. They expand the membership of the EU and extend the integrated policies to additional state territories. In principle, the acquis communautaire is supposed to be valid and applied in new member states on the first day of membership. The EU and the candidates may, however, agree on transitional arrangements. They determine a period of time, during which particular rules or policies do not apply.

Accession treaties do not involve any deepening for the old member states and therefore do not trigger the sovereignty concerns typical for treaty revisions. Non-member states may, of course, have reservations against the depth of sovereignty pooling and delegation entailed by membership but they know that the acquis communautaire is non-negotiable - except for transition periods, which would not help in the case of principled opposition to the EU's depth of integration. Therefore, they would rather refrain from applying for membership altogether if the level of EU integration was unacceptable to them (as in the case of Switzerland).

By contrast, enlargement generates concerns about efficiency and redistribution among the old member states. Old member states, or powerful interest groups in these states, fear economic and financial losses originating from market integration with the new member states (e.g. resulting from the opening up of labour markets), the redistribution of EU funds (e.g. in agriculture or regional policy), or weak implementation capacity (e.g. by expanding the Schengen regime before effective border controls are in place). New member states may in turn be concerned about pressures on domestic producers resulting from the opening up of their markets and losing competitiveness due to the obligation of implementing demanding regulatory rules. These concerns could give rise to 
treaty-based differentiation in the market and in core state powers. We do not observe differentiated integration that enlargement might produce in agricultural and regulatory policies here because these two areas are substantively regulated primarily through secondary legislation (Duttle et al., forthcoming). The market and core state power areas, while of course also the subject of secondary law-making, are governed more extensively by treaty rules.

As a result of asymmetrical interdependence, prospective new member states are, however, normally in a weak bargaining position vis-a-vis the EU (Moravcsik 1998: 3). Their markets are much smaller than the internal market, and bilateral trade with the EU is much more important to them than it is to the EU. As a consequence, candidate countries have more to gain from EU membership than the EU has to gain from accession of the candidate country, and candidate countries in the vicinity of the EU usually do not have credible outside options at all. This is especially true of the Central and Eastern European countries that have made up the bulk of applicants to EU membership in the past two decades (Moravcsik and Vachudova, 2005). Under these circumstances, the old member states are generally able to decide on the terms of the transitional arrangements with new member states. Whereas the old member states have always granted new member states temporary exemptions from the obligations of membership to facilitate their adaptation to market pressures and regulatory obligations (such as in the area of environmental standards) or to forestall popular fears and concerns (e.g. about foreigners buying land and holiday homes on a massive scale), they have also been able to exclude them temporarily from policies and rights in order to placate the most enlargement-sceptical member states or alleviate popular concerns in their own countries (Plümper and Schneider, 2007; Schneider, 2009). Examples are restrictions to the free movement of labour for the new member states, the phasing in of agricultural subsidies, and initial exclusion of new member states from Schengen and the monetary union in Eastern enlargement.

Differentiated integration in accession treaties is likely to affect poor new member states. First, poorer candidates generate particularly strong efficiency and redistribution concerns in the older member states. They will likely be net recipients of the EU budget, have problems of governance 
quality and capacity, and produce migratory pressure. These concerns trigger the old member states' interest in excluding them from some of the rights and benefits of membership. We acknowledge that the old members will not all be equally interested in transition periods - for instance, only some fear labour market migration. Yet, due to the need to assemble unanimous support for enlargement treaties, opposition of some countries is sufficient for differentiation demands to arise. Second, poor new members have weaker bargaining power than wealthier candidates because they are less attractive candidates, are more dependent on the benefits of membership, and are less likely to do well outside the EU. For these reasons, the old member states are not only more interested in but also more capable of imposing differentiated integration on them. We do not directly observe which old member state seeks to impose differentiation on the newcomers, but we can identify to which accession country differentiations in enlargement treaties apply. Bearing in mind that regulatory and agricultural policies are primarily regulated in secondary legislation (see above), this leads to our second expectation:

H2: In accession treaties, differentiated integration is more likely to apply to poor (rather than rich) new member states, albeit only in the market and core state powers.

\section{Research design and data}

Our analysis requires that we measure the occurrence or absence of differentiated integration, and the countries to which it applies. We do so at the level of what we call 'differentiation opportunities'. In order to identify these opportunities as precisely as possible, we first list all treaty revisions and accession treaties since 1990, summarised in Table $1 .^{3}$ Each treaty revision and accession treaty covers a number of policy areas, each of which constitutes an opportunity for a differentiation for any country involved in the negotiations. We demarcate policy areas based on the sections of EU treaties, which EU policy-makers also use to structure treaty revisions and accession negotiations. Moreover, we sort these disaggregated policy areas into the larger areas that the theoretical 
discussion refers to: the market, agriculture, regulatory policies, and core state powers (for an overview, see the online appendix). ${ }^{4}$ Technically speaking, our unit of analysis is the 'treaty-policycountry' combination. And our outcome of interest is the likelihood that a given country obtains a differentiation from a given policy area during the negotiations of a given treaty. We expect that national identities and wealth affect this likelihood in the manner, and conditional on the contexts, explained in the previous section.

---Table 1---

Let us add clarifications. First, the number of countries that participate in treaty negotiations varies. In treaty revisions, it increases over time as more countries join the Union (cf. Table 1). Thus, 27 states negotiated over each policy area covered by the Lisbon Treaty, in contrast to 12 at the Maastricht intergovernmental conference. In turn, each accession treaty generates differentiation opportunities only for the set of countries that joins at that particular point in time. For instance, Austria, Finland, or Sweden could obtain accession-related differentiations only in 1995, not in any later enlargement. Second, the set of policy areas that is being negotiated varies. This is important since countries cannot obtain differential arrangements in matters that are not even discussed. Simply speaking, negotiating the ESM Treaty does not create an opportunity to opt out of European transport policy. One reason for variation in policy areas is growth over time with every treaty revision. The number of policy areas with EU involvement has grown from 28 at the time of Maastricht to 37 at the time of the Lisbon Treaty. Thus, the Lisbon negotiations produced more opportunities than the ones in Maastricht. Similarly, late joiners such as Croatia have more enlargement-based differentiation opportunities than early joiners, simply because more policy areas are being negotiated at the time of accession. There is one more reason for variation in the set of negotiated policy areas: Treaty revisions do not necessarily deal with every last one of the EU's competences. Accession treaties cover the entire body of EU law, but treaty revisions may bracket some domains. Policy-specific treaties such as the ESM Treaty consist of only one policy area. Moreover, whereas the Maastricht and Lisbon negotiations encompassed nearly all of the EU's 
engagements, the Amsterdam and Nice conferences were narrower. Thus, we consulted primary documents and Börzel's (2005) data on the reform of decision-making procedures to identify what areas were in fact negotiated (for an overview, see the online appendix). The variation in countries and policy areas covered by treaties creates unbalanced data for treaty revisions and accession treaties. Below we also examine balanced sub-sets of the data - i.e. only the EU12 countries that participated in all treaty revisions; and only the policy areas that were part of all enlargement rounds.

Finally, we have to identify whether a country does or does not 'realise' a differentiation opportunity. A differentiation is a legal exemption from the validity of the rules that govern a policy area. For instance, Britain obtained a differentiation from monetary policy in the Treaty of Maastricht, whereas Germany did not. We rely on an existing dataset that tells us in detail whether any of the member states is exempted from any EU treaty rules in a policy area at any point in time. ${ }^{5}$ Whenever a new exemption in a given treaty and policy area applies to a country, we say that this country realised its differentiation opportunity. Note that we do not imply that the country realising a differentiation necessarily demanded one - in the enlargement context this is not necessarily the case.

Our measure of differentiations is binary: either an opportunity is realised or not. We acknowledge that, in theory, it makes sense to think that differentiation in one policy area, say monetary policy, might be more or less important or encompassing than in another, say the free movement of persons. Yet, as we explain elsewhere, it has proven hard to measure such gradation in differentiation in any way that does not generate more problems than it solves (Schimmelfennig and Winzen, 2014). Thus, we only capture whether new differentiations emerge or not for a country in a given area and treaty. We are also able to control for whether a country already had differentiations in place when an opportunity to acquire new ones arises. A first look at the data highlights that differentiation is a rather rare phenomenon. The member states used only 73 of the 1654 
opportunities to opt out of treaty revisions. New member states, however, have had to accept differential treatment more frequently, namely in 88 out of 420 opportunities.

Explanatory variables: To measure the strength of national identity, we rely on the widely used Eurobarometer item that asks respondents whether they feel 'exclusively national' rather than 'national and European', 'European and national' or 'European only' (e.g. Hooghe and Marks, 2005). The strength of national identity is the percentage of respondents feeling 'exclusively national'. From this percentage, we subtract the EU-wide average strength of national identity at a given point in time. Doing so focuses the measure on differences between the countries involved in a given differentiation opportunity. We draw on Eurobarometer surveys immediately prior to the differentiation opportunity in question. In the case of some enlargements, this is not possible because countries are included in the Eurobarometer only upon accession - so we use the first survey after accession. In the case of the Lisbon Treaty, we employ two surveys from immediately before the signature of the Constitutional Treaty and one from 2010 because the relevant question was not asked in between. ${ }^{6}$ The online appendix lists all consulted surveys.

We measure wealth in the year prior to a differentiation opportunity as GDP/capita in 2005 constant United States (US) Dollars based on data from the World Bank.

Control variables: Some of our analyses incorporate three control variables. First, we suspect that Eurosceptic governments might demand differentiated integration outcomes in intergovernmental negotiations. We derive party positions from the Chapel Hill and Leonard Ray expert surveys (Ray, 1999; Steenbergen and Marks, 2007; Bakker et al., 2015; Bakker et al., 2015), which are available at regular intervals throughout our period of analysis (i.e. 1992, 1996, 1999, 2002, 2006, 2010 and 2014). In order to fill in the years in between any two surveys, we assume that a party's position develops linearly from one survey to the next. On this basis, we calculate the seat-weighted average governmental party support for the EU, respectively in the year prior to a differentiation opportunity. Including this control variable means that we incur missing data for Cyprus, Malta, Luxembourg, and 
Estonia (before 2006). Furthermore, we control for institutional effects. Hooghe and Marks (2008) indicate that ratification referendums mobilise domestic public opposition to integration and put pressure on governments to demonstrate favourable negotiation outcomes, possibly through securing differentiation. Thus, we identify whenever a ratification referendum took place in the context of a differentiation opportunity. Finally, our analysis includes Henisz's (2002) 'Political Constraints' (POLCON) index as a general measure of a government's domestic constraints, which derives from formal legislative and executive veto points and the partisan composition of parliament and government.

--- Figure 1 ---

\section{Differentiation in enlargement treaties}

In the following, we first consider differentiation in the enlargement context and then in treaty revisions. Figure 1 shows the realisation of differentiation opportunities in enlargement treaties over policy areas. Agricultural and regulatory policies are not differentiated at all, for reasons explained earlier. Instead, new member states do not fully participate in the market and in core state powers.

Next, we describe the development of differentiation in the market and core state powers, and its relationship to the country characteristics wealth and identity (the corresponding figures are in the online appendix).Differentiation has increased over time, but especially strongly between the 1995 accession of Austria, Finland and Sweden, and the subsequent Eastern enlargements. The Croatian accession has produced most differentiation in the market as well as in core state powers. Does the level of differentiation of different accession countries correlate with their wealth or the strength of their national identity? In line with our expectations, rich countries experience less differentiation than their poor neighbours, both in the market and in core state powers. There clearly is no identity effect on differentiation in the market. It appears, however, that countries with strong national identity participate more fully in the EU's policies than their counterparts with more 'cosmopolitan' 
populations. Certainly, there is no sign that strong national identities reinforce differentiated integration in enlargements.

However, it is important to note two caveats. First, there are strong cohort effects, especially in core state powers but less in the market. In core state powers, the main difference lies between the relatively rich and nationally-oriented 1995 enlargement group and the subsequent Eastern cohorts. Within cohorts, neither wealth nor identity differences have a clear impact. In the market, some differences within cohorts, such as the fuller integration of countries such as Cyprus, Malta and Slovenia, could reasonably be related to the relatively better state of their economies. Even here, however, countries joining at the same time have similar levels of differentiation despite wealth differences.

Second, one might object that the set of differentiation opportunities expanded over time, alongside the range of policy competences of the EU. In the market, this is factually not the case. Since 1995, after the end of the EU's Single Market Programme and upon the conclusion of the Maastricht Treaty, the market-related competences of the EU have been stable. The decision-making procedures in some of these areas have become more centralised since. Nonetheless, both old and new member states in each accession round were aware that they would make joint market legislation in the future. In core state powers, however, the 2004 enlargement cohort, in contrast to the 1995 group, joined after visa, asylum and migration policies became supranational competences with Amsterdam; the 2007 cohort joined after the entry into force of the Prum Convention on criminal justice and law enforcement cooperation; and Croatia joined after the Lisbon Treaty adopted of the Charter of Fundamental Rights, and after the conclusion of the ESM and TSCG treaties. Different biases could result from the uneven set of differentiation opportunities, depending on what assumptions one makes. We, therefore, also consider only policy areas that were negotiated in all accession rounds (see the online appendix). As pointed out, the picture is exactly the same in the market. In core state powers, it becomes even clearer that the only real difference in 
differentiation in the data lies between the 1995 cohort, on the one hand, and all subsequent Eastern cohorts, on the other. Wealth is the factor that distinguishes these two groups sharply.

--- Table 2 ---

Modelling these data is problematic due to the limited amount of information available. Observations might be interdependent within countries, policy-subfields within the market such as free movement of persons, or within core state powers such as monetary union, and, as we have seen, enlargement rounds. With only 16 countries, eight (market) and twelve (core state powers) policy sub-fields, and four enlargement rounds, there are limits to the techniques we can plausibly use. Table 2 presents the results of two sets of three logistic regression models, respectively for the market and core state powers. We focus only on the two main variables of interest, in view of the fact that these, as well as our control variables, are measured at the country-level. Models 1 and 4 have country-clustered, Models 2 and 5 policy-clustered, and Models 3 and 6 treaty-clustered errors. Except for the country-clustered errors, these are all estimated through 5000 bootstrap replications. Estimating bootstrapped standard errors for Models 1 and 3 gives virtually identical results (see the online appendix).

The results support our argument to some extent but also show that there is too little empirical information to draw firm conclusions. Rich accession countries are less likely to experience differentiation, both in the market and in core state powers. The strength of newcomers' national identities does not matter in the market. In core state powers, there is even a tendency for nationally-oriented countries to participate more fully in the EU's policies than their 'cosmopolitan' counterparts. Possibly, the existing member states are less able to impose differentiation on these countries for fear of causing a domestic backlash against enlargement and, as a result, failed accession. However, these effects are accompanied by large uncertainty. They are insignificant in the models with either policy- or treaty-clustered errors. We already saw that the main differences in the extent of differentiation lie between the comparatively rich and nationally-oriented EFTA- 
enlargement cohort and the Central-East European countries. Furthermore, it appears to be the case that opt-outs concentrate in particular sub-fields of the market and core state powers. Discrimination in terms of free movement of workers and Schengen membership, which all new member states from the East faced, are examples. Bearing in mind the uncertainty just mentioned, taking a country's wealth into account makes a substantially relevant contribution to explaining differentiation in enlargement treaties. Comparing the richest to the poorest countries, the probability that they do not participate fully in a policy rises by around 20 (market) or ten (core state powers) percentage points (not shown, see the online appendix).

In sum, in the accession context, differentiated integration at the treaty level exists in the market as well as in core state powers, while being absent from agricultural and regulatory policies. There is a strong difference in the extent of differentiation in the enlargement treaties of the relatively rich EFTA cohort and the poorer Central and East European countries. Within enlargement rounds, we also observe a number of cross-country differences in line with the expected effect of wealth on differentiation. Our models suggest that the wealth effect is potentially important empirically, but it also remains uncertain whether it really is systematic, given the limited amount of country-, policy-, and treaty-level information that the EU's recent enlargement history provides. There is no sign that countries with strong national identities do not participate fully in all EU policies - if anything, they appear to participate more fully in core state powers than their 'cosmopolitan' neighbours.

\section{--- Figure 2 ---}

\section{Differentiation in treaty revisions}

Turning to the analysis of differentiation in treaty revisions, Figure 2 shows that countries do not optout from any area other than from core state powers. In market, agricultural and regulatory policies, differentiation arises only from enlargement (see above) or secondary legislation (Duttle et al., 
forthcoming). Core state powers, in turn, encourage national opt-outs in a small but non-negligible number of opportunities arising from treaty revisions.

Let us examine the development of differentiation in core state powers over treaty revisions, as well as its relation to wealth and identity at the country-level (the corresponding figures are in the online appendix). We consider two groups: All member states, and also the first 12 - a group which faced an identical set of differentiation opportunities since the 1990s, and whose differentiation outcomes are not potentially shaped by differentiation resulting from their earlier accessions. First, there is no general trend for member states to use more of their opportunities to opt-out. They realised four percent at Maastricht and seven percent at Lisbon. The policy-specific treaties in the areas of justice and home affairs as well as economic and monetary union strongly raise the share of used differentiation opportunities. In the case of the ESM and TSCG treaties, however, the effect is less pronounced if we do not consider the countries that joined the EU during the 1990s and 2000s. Analysing all member states, a negative relationship appears to exist between wealth and differentiation in EU treaty revisions. However, this effect is clearly driven by the 2004-2013 Eastern accession cohorts, whose differentiations can be traced back to the initial opt-outs in their accession treaties. Taking only the EU12 into account, in which differentiation outcomes are unrelated to accession arrangements, there is no visible connection between countries' wealth and their opt-outs. If anything, excluding Luxembourg, an outlier in terms of GDP per capita, the relationship between wealth and differentiation is positive. In turn, in line with expectations, countries with strong national identities realise more of their differentiation opportunities in core state powers than other member states. This relationship exists in the EU12 as well as in the group of all countries, even though it is also reinforced by the accession rounds since 2004 .

--- Table 3 ---

Table 3 shows the results of five logistic regression models of new differentiations in treaty revisions. They focus on the EU's 12 initial member states. For these countries, the logic underlying our 
expectations should work clearly. For countries that joined the Union since the 1990s, the accession heritage has generated follow-up differentiations, which we do not expect or argue to reflect strong national identities. The initial twelve member states also faced exactly the same differentiation opportunities. Furthermore, the models analyse the area of core state powers only because other areas have not produced any differentiation in treaty revisions. All models include country-clustered standard errors. In view of the limited number of countries, we also compare these to normal, bootstrapped and jackknife country-clustered errors and present several additional robustness tests, discussed below (see the online appendix). Finally, the models all control for ongoing differentiations in a policy sub-field, as it is highly likely that countries obtain follow-up opt-outs once they have initially decided not to participate. Economic and monetary union would be a case in point in which countries that did not join at Maastricht are unlikely to participate in any further developments.

Model 1 in Table 3 shows a positive effect of the strength of a country's national identity on its probability to opt-out of core state powers in treaty revisions. This effect holds in Model 2 which adds treaty dummy variables, in view of the possibility that average differences between treaties could interfere with the results. Identity continues to matter after adding additional control variables in Model 3, which themselves do not have significant effects, except for governmental support for the EU, which makes differentiations less likely. Models 4 and 5, finally, disaggregate the analysis still further, focussing only on sub-fields in the domain of core state powers, namely economic and monetary union and justice and interior policies, to engage with the suspicion that these two areas are too different to be analysed together. However, the estimated identity effect is nearly identical, albeit significant only at the .1 level in economic and monetary union. We take this as justification to combine the analysis of these two areas. The third area in the realm of core state powers, external security, has too few observations to be studied separately. Overall, the consistently positive identity effect is in line with our expectations.

Furthermore, we observe, plausibly, that ongoing differentiations have a positive effect on a country's probability to obtain a new differentiation in the same sub-field. While we did not expect a 
wealth effect in treaty revisions, we do find a positive effect. Rich countries are more likely to opt-out than their poorer neighbours. This certainly underlines that wealth does not work in the same way in treaty revisions compared to enlargements, where poor countries are likely not to participate fully in EU rules.

We conduct a number of robustness tests (see the online appendix). First, we re-estimate the models with only the main treaties to make sure that they do not depend on the highly differentiated policyspecific treaties such as on Schengen or the ESM. This is not the case, however. If anything, the identity effect becomes more pronounced. Second, we estimate normal standard errors (Model 2), as well as bootstrapped standard errors on the basis of repeated draws of random samples of countries (Model 3), or treaty revisions (Model 4). The errors that we thus estimate for the identity effect differ only marginally from the ones presented in Model 1 of Table 3. However, they increase considerably around the positive effect of wealth, which becomes insignificant. The same holds true if we estimate jackknife errors based on repeatedly estimating the model with one of the countries removed. While the identity effect remains robust, the wealth effect becomes insignificant. It remains insignificant in Models 4 and 5 when excluding Luxembourg from the analysis, while being significant at the .1 level in Model 3. We conclude from these tests that the strength of national identity positively affects the probability that a country opts-out from treaty revisions. We cannot rule out that wealth might have a positive effect - clearly, however, it does not have the negative effect that, if anything, prevails in the enlargement context.

Figure 3 shows the probability of differentiation for various levels of a country's national identity, and also probabilities that Model 1 in Table 3 suggests for three past differentiation opportunities. Comparing countries with weak to strong national identities in panel a), the probability that a country realises a given differentiation opportunity increases by about 15 percentage points. Due to the quite wide confidence intervals, this effect could, however, also be slightly below ten percentage points. Panel b) shows the predicted differentiation probabilities of the EU12 member states from economic and monetary union in the Maastricht Treaty; panel c) from the supranational side of 
justice and interior policies in the Amsterdam Treaty, namely visa, asylum and migration policies; and panel d) from the ESM treaty. In all three cases, predicted differentiation probabilities are highest for the countries that acquired opt-outs, Britain and Denmark and, in the justice area, Ireland. Comparing panel b) to d), the ESM treaty, it also becomes clear that the expected inclination of certain countries to opt-out becomes very strong if they already have prior opt-outs in a policy area, as one would expect. In the case of the ESM treaty, for instance, it was not inconceivable but certainly hard to imagine that Britain and Denmark would have participated, in light of their outsider status in the Eurozone.

--- Figure 3 ---

In sum, bearing in mind the limited amount of information that the EU's recent history provides on differentiated integration, we find noteworthy evidence in line with our expectations. First, differentiation in treaty revisions arises entirely in core state powers. Second, the countries acquiring differentiations are the ones with a strong national identity, specifically Britain and Denmark. We cannot rule out that wealth matters alongside identity but the findings are inconsistent. Clearly, however, wealth does not have the negative effect that we observe in the enlargement context. Finally, differentiated integration has a tendency to re-produce itself in that countries are likely to opt-out from further developments of policy domains in which they do not participate fully.

\section{Conclusion}

Differentiated integration has become a standard and durable feature of EU treaty-making. Both treaty revisions and accession treaties regularly contain provisions granting policy-specific opt-outs and exemptions to some countries and excluding others from full integration into the EU's policies. In this article, we have analysed why some countries and policies are more strongly characterized by differentiated integration than others. 
Our analysis started from the assumption that differentiated integration responds to increasing heterogeneity of preferences and capabilities resulting from the expansion of the EU to additional policy areas, higher levels of centralization, and new member states. We also built on earlier descriptive work suggesting that deepening and widening constitute different contexts of differentiated integration, which require different explanations. In the case of deepening, countries with stronger national identities are concerned about the EU undermining national sovereignty in core state powers. Because of their bargaining power as defenders of the institutional status quo, these countries are able to achieve opt-outs from undesired deepening. In line with this reasoning, our analysis found that differentiation opportunities provided by negotiations on treaty revisions are, indeed, more likely to be realized by member states with strong national identities, albeit exclusively in the area of core state powers. By contrast, in the context of widening, superior bargaining power rests with the old member states. They are concerned about losses resulting from inefficiency, competition, and redistribution due to enlargement. Our analysis found some support for the view that poorer new member states, which are likely to suffer from weak governance capacity, provide low-cost labour, and become net recipients of the EU budget, are more affected by the transitional differentiation arrangements of accession treaties. Yet, we acknowledge that wealth mainly distinguishes richer from poorer groups of accession countries rather than countries that join at the same time. Because the historical record of the EU includes only few enlargement rounds, we cannot say with certainty whether the patterns we find are systematic. Certainly, however, we find no sign of strong national identities enhancing differentiation in enlargement, or poverty encouraging optouts from treaty revisions - if anything, the opposite might be true. This corroborates the assumption of the existence of two qualitatively different contexts of differentiated integration, constituted by treaty revisions and accession.

While we do not by any means rule out the relevance of more case-specific preference constellations and bargaining dynamics that we could not fully consider here, understanding the impact of systematic, structural factors and policy characteristics on differentiated integration contributes 
importantly to our understanding of the EU's political development. Our findings suggest that differentiation will continue to characterize treaty-making in the EU. First of all, existing differentiations tend to persist and even produce more differentiation in later treaty negotiations. Second, future enlargements are most likely to integrate the relatively poor countries of the Western Balkans. Already the accession treaty with Croatia exhibited a record number of differentiations. Finally, national identities show no tendency of diminishing, and any future treaty revision is likely to affect core state powers. The persistence and likely growth of differentiation means that policymakers and academics alike should now also begin to investigate more systematically what effects it may have on important outcomes such as policy convergence (e.g. Dimitrova and Steunenberg, 2000), compliance (Zhelyazkova, 2014), or public and elite support for and identification with European integration.

\section{Acknowledgments}

This paper builds on the EUDIFF1 database of differentiation in EU treaty law that has been assembled as part of a research project on 'Differentiated Integration in Europe', co-directed by Katharina Holzinger (University of Konstanz) and Frank Schimmelfennig (ETH Zurich), and funded by the German Research Foundation (DFG) and the Swiss National Science Foundation (SNSF). For their support in coding the data, we further thank Claudia Baumgartner, Laura Gies, Sebastian Müller, Anna Reimann, Olga Sierocinska, Mario Trost, and Dagmar Zakopalova. For comments on earlier versions, we thank Stefanie Bailer, participants at the 'Differentiated Integration' workshop (13-14 November 2014, University of Konstanz) and the EUSA Conference (5-7 March 2015, Boston), and the EUP referees and editors. The appendix and replication materials are available online at the EUP website.

\section{Notes}

1. For reasons of space, we provide additional comments on the literature in the online appendix.

2. See Schmitter (1969) and Börzel (2005) on definitions and measurements of level and scope.

3. Before the 1990s, differentiated integration was rare and short-lived (Schimmelfennig and Winzen, 2014). 
4. A number of treaty sections fall in the area 'institutions', which does not contain any differentiations and to which our argument does not clearly apply. We omit this area in the following.

5. The so-called 'EUDIFF1' dataset covers treaty-based differentiation from 1952 to 2013 in the legally binding parts of EU treaties (main parts, protocols and annexes). The dataset has article-years as its unit of observation. For more information on the dataset, see (Schimmelfennig and Winzen, 2014).

6. Note that the Lisbon Treaty took over most of the substantive agreements made in the Constitutional Treaty. Thus, our measurement, even if taken several years before the Lisbon Treaty, should nonetheless capture the conditions under which policy-makers negotiated. 


\section{References}

Adler-Nissen R (2008) The Diplomacy of Opting Out: A Bourdieudian Approach to National Integration Strategies. Journal of Common Market Studies 46: 663-684.

Adler-Nissen R (2009) Behind the scenes of differentiated integration: circumventing national optouts in Justice and Home Affairs. Journal of European Public Policy 16(1): 62-80.

Adler-Nissen R (2011) Opting Out of an Ever Closer Union: The Integration Doxa and the Management of Sovereignty. West European Politics 34(5): 1092-1113.

Bakker R, De Vries C, Edwards E, et al. (2015) Measuring Party Positions in Europe: The Chapel Hill Expert Survey Trend File, 1999-2010. Party Politics 21(1): 143-52.

Bakker R, Edwards E, Hooghe L, Jolly S, Marks G, Polk J, et al. (2015) 2014 Chapel Hill Expert Survey. Version 2015.1. Chapel Hill, NC: University of North Carolina, Chapel Hill. Available on http://chesdata.eu/ (accessed 01 August 2015).

Börzel TA (2005) Mind the gap! European integration between level and scope. Journal of European Public Policy 12(2): 217-236.

Carey S (2002) Undivided Loyalties: Is National Identity an Obstacle to European Integration? European Union Politics 3(4): 387-413.

de Vries CE (2007) Sleeping Giant: Fact or Fairytale?: How European Integration Affects National Elections. European Union Politics 8(3): 363-385.

de Vries CE and Edwards EE (2009) Taking Europe To Its Extremes: Extremist Parties and Public Euroscepticism. Party Politics 15(1): 5-28.

Dimitrova A and Steunenberg B (2000) The Search for Convergence of National Policies in the European Union: An Impossible Quest? European Union Politics 1(2): 201-226.

Duttle T, Holzinger K, Malang T, et al. (forthcoming) Opting out from European Union Legislation: The Differentiation of Secondary Law. Journal of European Public Policy.

Dyson K and Sepos A (2010) Differentiation as Design Principle and as Tool in the Political Management of European Integration. In: Dyson K and Sepos A (eds) Which Europe? Basingstoke: Palgrave, pp. 3-23.

Genschel P and Jachtenfuchs M (2014) Introduction: Beyond Market Regulation. Analysing the European Integration of Core State Powers. In: Genschel P and Jachtenfuchs M (eds) Beyond the Regulatory Polity? The European Integration of Core State Powers. Oxford: Oxford University Press, pp. 1-23.

Henisz WJ (2002) The institutional environment for infrastructure investment. Industrial and Corporate Change 11(2): 355-389.

Hoffmann S (1966) Obstinate or Obsolete? The Fate of the Nation-State in the Case of Western Europe. Daedalus: Journal of the American Academy of Arts and Sciences 95: 862-915.

Holzinger K and Schimmelfennig F (2012) Differentiated Integration in the European Union: many concepts, sparse theory, few data. Journal of European Public Policy 19(2): 292-305.

Hooghe L and Marks G (2005) Calculation, Community and Cues: Public Opinion on European Integration. European Union Politics 6(4): 419-443.

Hooghe L and Marks G (2008) A Postfunctionalist Theory of European Integration: From Permissive Consensus to Constraining Dissensus. British Journal of Political Science 39(01): 1-23.

Jensen CB and Slapin JB (2012) Institutional hokey-pokey: the politics of multispeed integration in the European Union. Journal of European Public Policy 19(6): 779-795.

Kölliker A (2001) Bringing together or driving apart the union? Towards a theory of differentiated integration. West European Politics 24(4): 125 - 151.

Kölliker A (2006) Flexibility and European Unification: The Logic of Differentiated Integration. Lanham: Rowman and Littlefield. 
Kriesi H, Grande E, Lachat R, Dolezal M, Bornschier S and Frey T (2006) Globalization and the transformation of the national political space: Six European countries compared. European Journal of Political Research 45(6): 921-956.

Majone G (2009) Europe as the Would-Be World Power. The EU at Fifty. Cambridge: Cambridge University Press.

Moravcsik A (1998) The Choice for Europe: Social Purpose and State Power from Messina to Maastricht. Ithaca, New York: Cornell University Press.

Moravcsik A and Vachudova M (2005) Preferences, Power, and Equilibrium: The Causes and Consequences of EU Enlargement. In: Schimmelfennig F and Sedelmeier U (eds) The Politics of European Union Enlargement: Theoretical Approaches. London: Routledge, pp. 198-212.

Plümper T and Schneider CJ (2007) Discriminatory European Union Membership and the Redistribution of Enlargement Gains. Journal of Conflict Resolution 51(4): 568-587.

Ray L (1999) Measuring party orientations towards European integration: Results from an expert survey. European Journal of Political Research 36(2): 283-306.

Schimmelfennig F and Winzen T (2014) Instrumental and Constitutional Differentiation in the European Union. Journal of Common Market Studies 52(2): 354-370.

Schmitter P (1969) Three Neo-Functional Hypotheses about International Integration. International Organization 23(1): 161-166.

Schneider CJ (2009) Conflict, Negotiations, and EU Enlargement. Cambridge: Cambridge University Press.

Steenbergen M and Marks G (2007) Evaluating Expert Surveys. European Journal of Political Research 46(3): 347-366.

Stubb ACG (1997) The 1996 Intergovernmental Conference and the management of flexible integration. Journal of European Public Policy 4(1): 37-55.

Tomz M, Wittenberg J and King G (2003). CLARIFY: Software for Interpreting and Presenting Statistical Results. Version 2.1.Unpublished manuscript, Stanford University, University of Wisconsin, and Harvard University. January 5. Available at http://gking.harvard.edu/ (accessed 01 August 2015).

Warleigh A (2002) Flexible Integration. Which Model for the European Union. Sheffield: Sheffield University Press.

Zhelyazkova A (2014) From selective integration into selective implementation: The link between differentiated integration and conformity with EU laws. European Journal of Political Research 53(4): 727-746. 


\section{Tables and figures}

Table 1. Treaties generating differentiation opportunities.

\begin{tabular}{lll}
\hline $\begin{array}{l}\text { Treaty revisions and member states } \\
\text { at the time of negotiation }\end{array}$ & Accession treaties \\
\hline Maastricht Treaty (1993) & 12 & \\
Schengen Treaty (1995) & 12 & Austria, Finland, Sweden (1995) \\
Amsterdam Treaty (1999) & 15 & \\
Nice Treaty (2003) & 15 & Eight CEECs, Cyprus, Malta (2004) \\
Prum Convention (2006) & 25 & Bulgaria, Romania (2007) \\
Lisbon Treaty (2010) & 27 & \\
ESM Treaty (2012) & 27 & \\
TSCG (2013) & 27 & Croatia (2013) \\
\hline
\end{tabular}

Note: ESM: European Stability Mechanism. TSCG: Treaty on Stability, Coordination and Governance. CEECs: Central and Eastern European countries. In parentheses: year of entry into force.

Figure 1. Accession differentiation by policy area.

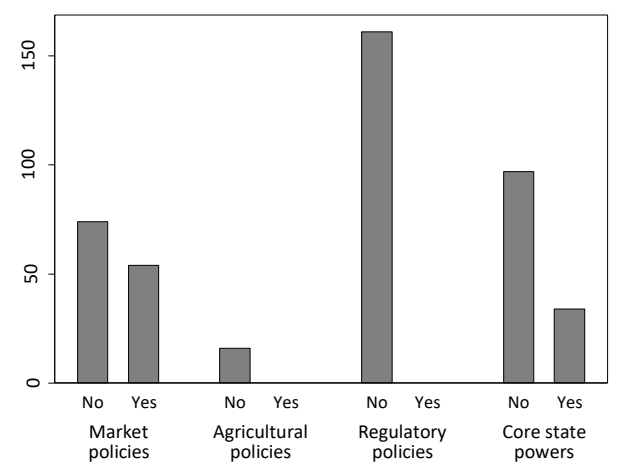


Table 2. Logistic Regression models of differentiation in accession treaties.

\begin{tabular}{lllllll}
\hline & $\begin{array}{l}\text { 1) Country- } \\
\text { clustered SE }\end{array}$ & $\begin{array}{l}\text { 2) Policy- } \\
\text { clustered SE }\end{array}$ & $\begin{array}{l}\text { 3) Treaty- } \\
\text { clustered SE }\end{array}$ & $\begin{array}{l}\text { 4) Country- } \\
\text { clustered SE }\end{array}$ & $\begin{array}{l}\text { 5) Policy- } \\
\text { clustered SE }\end{array}$ & $\begin{array}{l}\text { 6) Treaty- } \\
\text { clustered SE }\end{array}$ \\
\hline Policy area & Market & Market & Market & Core & Core & Core \\
Identity & $.009(.007)$ & $.009(.011)$ & $.009(.086)$ & $-.018(.007)^{*}$ & $-.018(.195)$ & $-.018(.026)$ \\
Wealth & $-.044(.013)^{* *}$ & $-.044(.047)$ & $-.044(.089)$ & $-.033(.004)^{* *}$ & $-.033(.160)$ & $-.033(.037)$ \\
Constant & $.249(.160)$ & $.249(1.097)$ & $.249(1.262)$ & $-.607(.100)^{*}$ & $-.607(.843)$ & $-.607(.536)$ \\
\hline $\mathrm{N}$ & 128 & 128 & 128 & 131 & 131 & 131 \\
Log-pseudolikelihood & -85.204 & -85.204 & -85.204 & -73.809 & -73.809 & -73.809 \\
\hline
\end{tabular}

Note: ${ }^{*} p<0.05 ;{ }^{* *} p<0.01$. SE: Standard errors. The standard errors in Models 2, 3, 5, and 6 result from 5000 bootstrap replications, based on policy (Models 2 and 5 ) and treaty ( 3 and 6) clusters respectively. Less than one percent of the bootstrap replications fail. The estimates are based on the successful replications only. Estimating bootstrapped standard errors, based on country clusters, for Models 1 and 3 yields nearly identical results (see Table A3 in the online appendix).

Figure 2. Differentiation in treaty revisions by policy area.

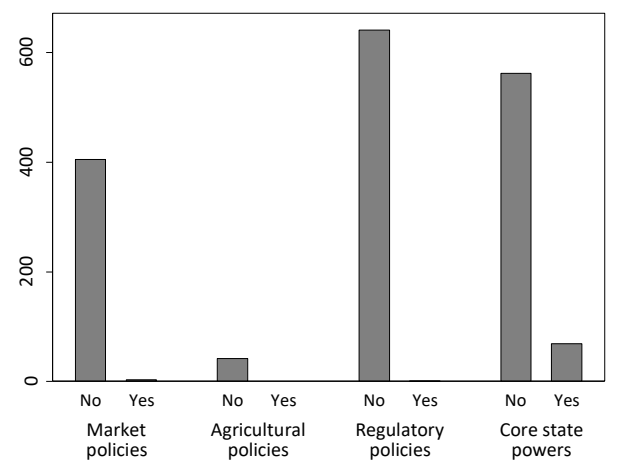


Table 3. Logistic regression models of differentiation in treaty revisions in the EU12 countries.

\begin{tabular}{|c|c|c|c|c|c|}
\hline & 1) Main variables & 2) Treaty dummies & $\begin{array}{l}\text { 3) Control } \\
\text { variables }\end{array}$ & $\begin{array}{l}\text { 4) Only } \\
\text { EMU }\end{array}$ & $\begin{array}{l}\text { 5) Only } \\
\text { Interior }\end{array}$ \\
\hline Identity & $.062(.017)^{* *}$ & $.108(.028)^{* *}$ & $.040(.018)^{*}$ & $.065(.037)^{\prime}$ & $.068(.016)^{* *}$ \\
\hline Wealth & $.032(.013)^{*}$ & $.053(.025)^{*}$ & $.053(.028)^{\prime}$ & $.029(.025)$ & $.033(.011)^{* *}$ \\
\hline Ongoing DI & $1.725(.271)^{* *}$ & $2.725(.519)^{* *}$ & $1.551(.423)^{* *}$ & $2.778(.657)^{* *}$ & $.799(.274)^{* *}$ \\
\hline Govt. EU support & & & $-.543(.271)^{*}$ & & \\
\hline Referendum & & & $-.438(.372)$ & & \\
\hline POLCON index & & & $.119(.746)$ & & \\
\hline Treaty dummies & No & Yes & No & No & No \\
\hline Constant & $-3.918(.469)^{* *}$ & $-5.046(.749)^{* *}$ & $-1.355(1.884)$ & $-4.551(1.047)^{* *}$ & $-3.321(.508)^{* *}$ \\
\hline $\mathrm{N}$ & 408 & 324 & 373 & 120 & 192 \\
\hline Log-pseudolikelihood & -94.948 & -53.541 & -87.414 & -19.681 & -61.762 \\
\hline
\end{tabular}

Note: ' $p<0.1{ }^{*} p<0.05 ;{ }^{* *} p<.01$. EMU: Economic and monetary union. Interior: Justice and internal security policies. Model 2 has fewer observations than Model 1 because the Nice Treaty did not produce any differentiations, which is why the corresponding observations are not included in Model 2. 
Figure 3. Predicted differentiation probabilities over identity and for three differentiation opportunities.

a) The effect of identity on differentiation

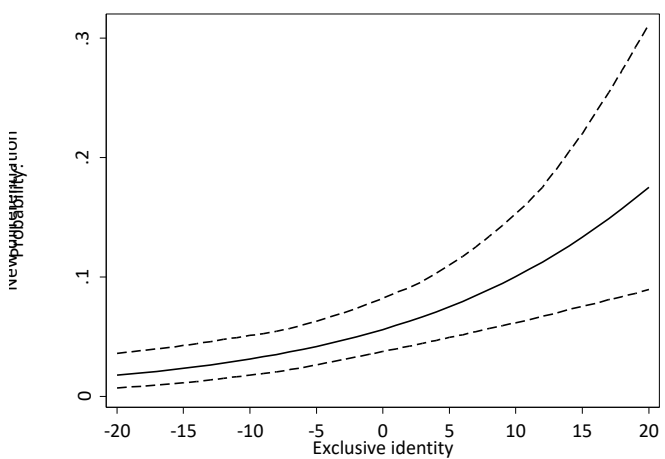

c) Predicted differentiation probabilities: Visa, Asylum, Migration in the Amsterdam Treaty

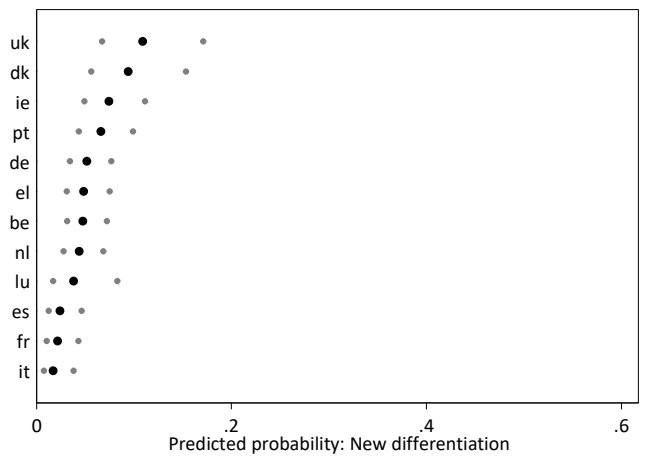

b) Predicted differentiation probabilities: EMU in the Maastricht Treaty

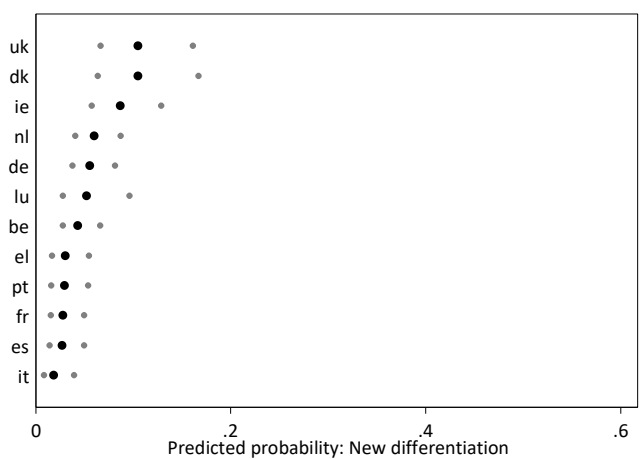

d) Predicted differentiation probabilities: ESM Treaty

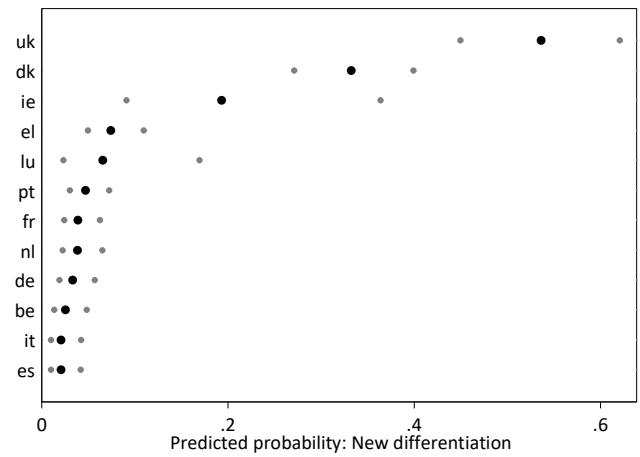

Note: Based on Model 1 in Table 3. Dotted lines (panel a) and grey dots (panels b to d): 95 percent confidence intervals. Panel (a) is based on simulated probabilities estimated with the help of Clarify (Tomz et al., 2003). EMU: Economic and monetary union. ESM: European Stability Mechanism. 